\title{
Unlocking the mystery of plants' survival capability under waterlogging stress
}

\author{
Kazi Khayrul Bashar*, Md. Zablul Tareq \& Md. Shahidul Islam \\ Basic and Applied Research on Jute Project, Bangladesh Jute Research Institute, Manik Mia Avenue, Dhaka 1207, Bangladesh \\ *Email: kazi.khayrulbashar@gmail.com
}

\section{ARTICLE HISTORY}

Received: 24 November 2019

Accepted: 20 January 2020

Published: 01 April 2020

\section{KEYWORDS}

Waterlogging; crop plants; signaling and physiological pathways; survival mechanism

\begin{abstract}
Waterlogging is a major abiotic stress affecting crop plants throughout the world, which hampers crop growth and causes yield loss. There are various types of responses in plants under this stress through the combined operation of different signaling and physiological pathways. However, the correlation between these pathways is extremely limited and not well described in the published papers. Therefore, the complex waterlogging stress-tolerance mechanisms need to be presented most coherently for a comprehensive understanding of this stress. Here, we present sequential responses in plants under oxygen-deprivation stress. The regulation of the $\mathrm{N}$-end rule pathway may be treated as the initial signaling in plants after facing waterlogging stress, but still, it remains a controversial topic. All the pathways under waterlogging stress are directly or indirectly related to glycolysis, tricarboxylic acid (TCA) cycle, programmed cell death (PCD) and removal of reactive oxygen species (ROS). Scientists may consider alanine aminotransferase as the main controlling switch for surviving of plants under waterlogging stress. Triggering the genes responsible for alanine aminotransferase may act as a crucial one to develop a waterlogging tolerant plant due to its ability to control anaerobic fermentation, TCA cycle and efficient utilization of carbons.
\end{abstract}

\section{Introduction}

Plants face several abiotic stresses, such as waterlogging, salinity, drought, extreme temperature, ion toxicity or deficiency, high wind and others (1). Among these, flooding and/or waterlogging are unavoidable threats throughout the world, especially in lowland areas. Oxygen-limiting stresses, such as waterlogging, flooding and submergence, significantly affect crop growth, development and yield (2). Plants cope with waterlogging stress by different morphological, anatomical, physiological, biochemical and molecular signaling mechanisms. Among these, physiological and molecular signaling mechanisms control the other responses directly or indirectly (3). There have been a lot of reports based on morphological and anatomical changes and regulation of specific genes under waterlogging stress. The molecular physiological response is equally available but needs to be consolidated in an updated review. Different signaling and physiological pathways expressed under waterlogging stress are still uncorrelated with each other to provide a complete picture. Therefore, it is essential to present these complex mechanisms in a simple and well understandable form, and to know how plants respond under waterlogging stress.

\section{Waterlogging stress-related signals}

At the beginning of waterlogging stress, the internal oxygen concentration of the plant decreases, resulting in a declining amount of aerobic respiration. Besides, rapid accumulation of ethylene in the submerged tissues is an early and reliable waterlogging stress signal (4).

In ethylene biosynthesis pathway, methionine is converted to S-adenosyl-methionine (SAM), catalyzed by SAM synthase followed by the formation of 1aminocyclopropane-1-carboxylic acid (ACC) by ACC synthase (ACS). Finally, ethylene is formed from ACC by ACC oxidase (ACO) in the presence of oxygen (5). Therefore, in the submerged root, ethylene production is restricted because of the inactivation of ACO in the

(c) Bashar et. al.(2020). This is an open-access article distributed under the terms of the Creative Commons Attribution License, which permits unrestricted use, distribution, and reproduction in any medium, provided the original author and source are credited (https://creativecommons.org/licenses/by/4.0/).

To cite this article: Bashar KK, Tareq MZ, Islam MS. Unlocking the mystery of plants' survival capability under waterlogging stress Plant Science Today. 2020; 7(2):142153. https://doi.org/10.14719/pst.2020.7.2.663 


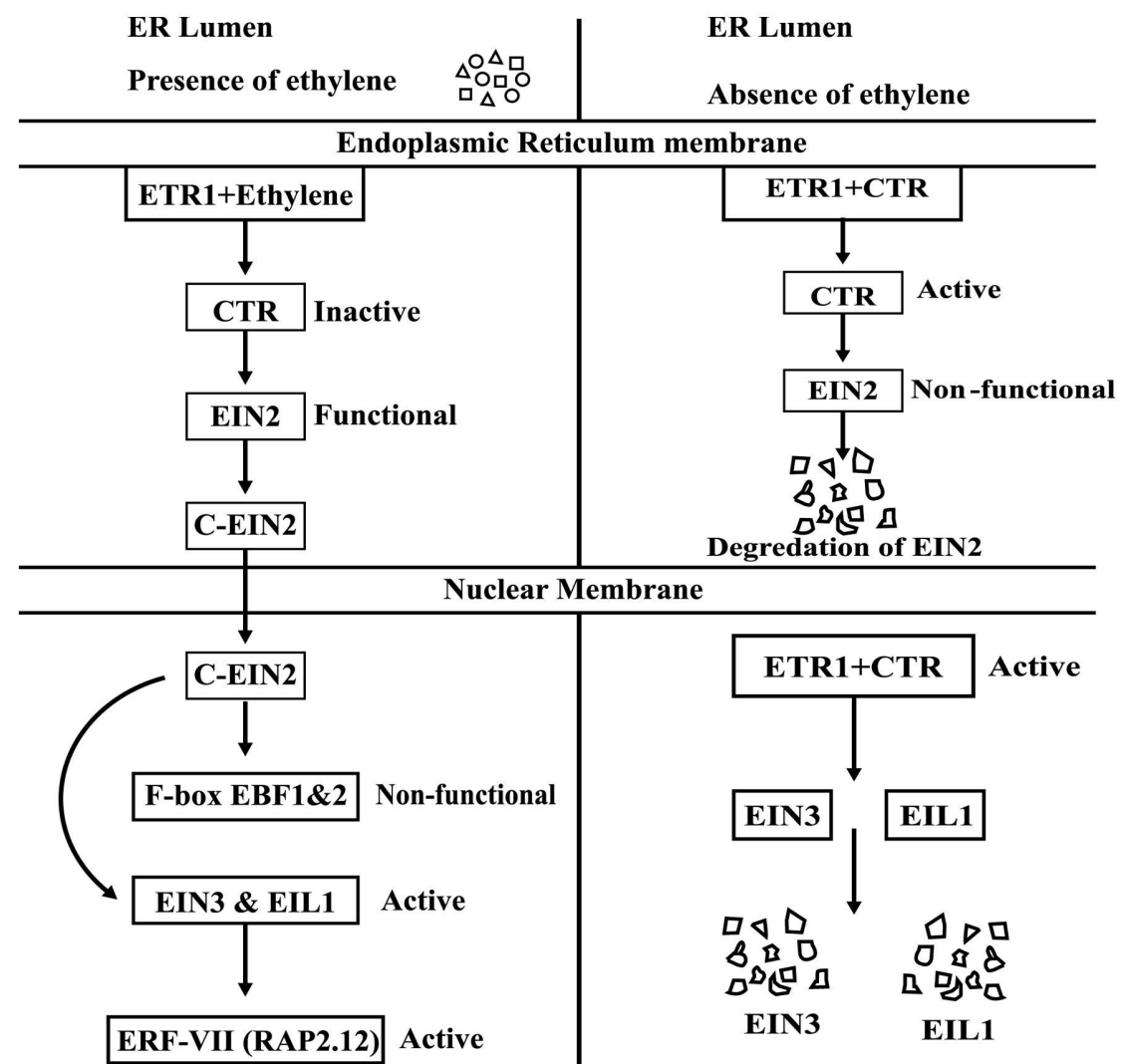

Waterlogging responsive primary genes

Degredation of EIN3 \& EIL1

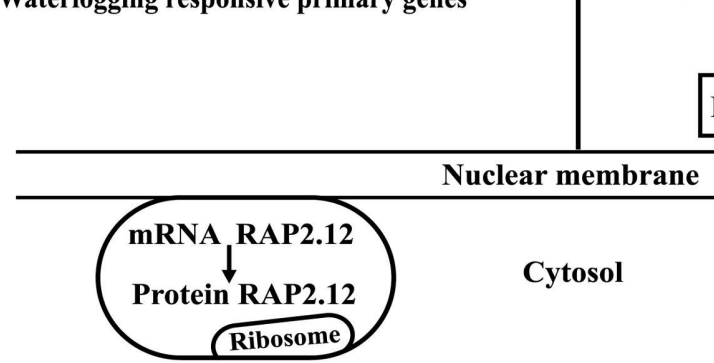

Cell Membrane

Fig. 1. Activation of ERF-VII (RAP2.12) through the accumulation of ethylene under waterlogged stress. Modified figure (13). CTR1: Constitutive triple response1; EBF1: EIN3 binding F-BOX protein1; EBF2: EIN3 binding F-BOX protein2; EIN2: Ethylene insensitive2; EIN3: Ethylene insensitive3; EIL1: EIN3-like1; ER: Endoplasmic reticulum; ERF-VII: Ethylene response factor-VII; ETR1: Ethylene response1; RAP2.12: Related to Apatala2

absence of oxygen. At this situation, ethylene precursor ACC is transported from anoxic (complete absence of oxygen) roots to the normaxic part (shoots) in the transpiration stream via the root-shoot vasculature (6). Initial stages of waterlogging stress, soil oxygen is partially depleted, plant root produces more ethylene due to the faster ethylene biosynthesis pathway and lowering ethylene efflux to water. But in the later stages, soil oxygen is almost completely depleted then the newly formed adventitious roots produce more ethylene by using available oxygen at the water surface region (6).

\section{Ethylene signaling pathway in plants}

Arabidopsis plant has already provided a complete pathway of expressing ethylene-responsive genes from ethylene reception to the endoplasmic reticulum (ER) through the ethylene signaling pathway (7). Ethylene is perceived by five ER membranes located ethylene receptors such as ETR1 (Ethylene response1), ETR2 (Ethylene response2), ERS1 (Ethylene response sensor1), ERS2 (Ethylene response sensor2) and EIN4 (Ethylene insensitive4) (8-10). ETR1 ethylene receptor also locates in the Golgi apparatus in Arabidopsis (11). Whereas, tobacco ethylene receptor NTHK1 (Nicotiana tabacum Histidine kinase1) is located at the cell membrane (12). However, the ER membrane is generally considered as the primary site of ethylene receptors.

Ethylene receptor activates cytosol located CTR1 (Constitutive triple response1) serine/threonine protein kinase through direct physical interaction under the absence of ethylene or low level of ethylene (Fig. 1). CTR1 suppresses the function of ER membrane located Nramp-like protein EIN2 (Ethylene insensitive2) (13). At this time, two key 


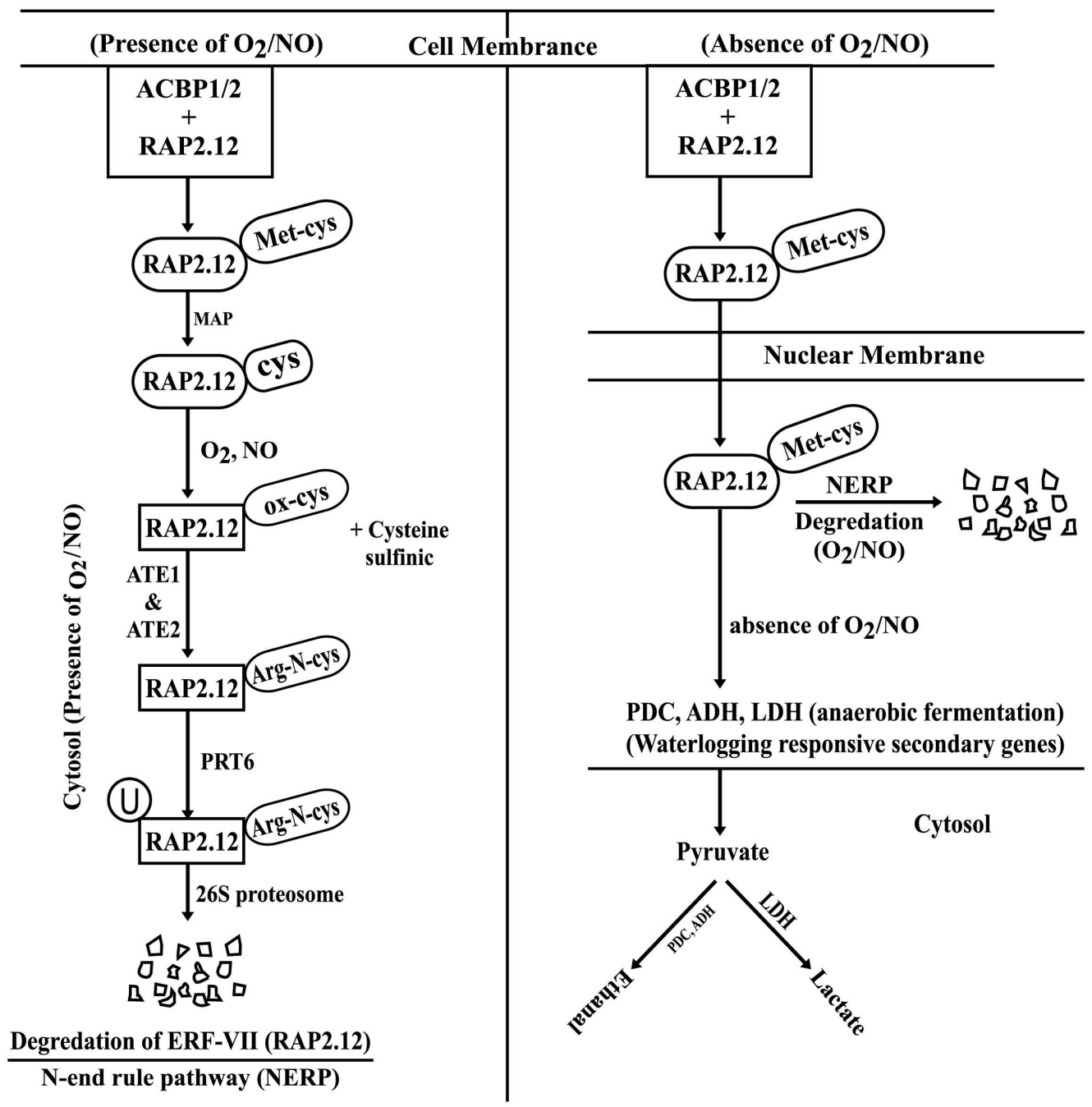

Fig. 2. Activation of fermentation genes through ERF-VII (RAP2.12) signaling during absence of O2/NO. Modified figure (28). ACBP1/2: AcylCoA binding protein1/2; ADH: Alcohol dehydrogenase; ATE: Arginine-tRNA protein transferases; cys: cysteine; ERF-VII: Ethylene response factor-VII; LDH: Lactate dehydrogenase. MAP: Methionine aminopeptidase; ox-cys; oxidation of the N-terminal cysteine; NO: Nitric oxide; PDC: Pyruvate decarboxylase; PRT6: Proteolysis6; RAP2.12: Related to Apatala 2

transcription factor EIN3 (Ethylene insensitive3) and EIL1(EIN3-like1) are degraded into the nucleus by the F-box proteins EBF1 (EIN3 binding F-box protein1) and EBF2 (EIN3 binding F-box protein2) through a $26 \mathrm{~S}$ proteasome-mediated degradation pathway (14, 15). Ethylene binds with the ethylene receptor and disrupts the direct physical interaction between ethylene receptors and CTR1 in the presence of a high level of ethylene. Thus, CTR1 loses its function to suppress EIN2. Then the C-terminal fragment of EIN2 i.e. EIN-C' shuttles into the nucleus and enhances the levels of two key transcription factor named EIN3 and EIL1. These two EIN3 and EIL1 activate different primary responsive genes or transcription factors such as ERF (Ethylene response factor), CHIB (ChitinaseB), PORA (Protochlorophyllide oxidoreductase A) and FLS2 (Flagellin sensitive2). Finally, these primary genes activate secondary responsive genes that allow plants to respond to specific stress through the ethylene signaling pathway $(14,15)$.

It would involve ERF group VII in Arabidopsis in the direct oxygen-sensing mechanisms. ERF-VII comprises HRE1 (ERF73), HRE2 (ERF71), RAP2.2 (ERF75), RAP2.12 (ERF74), RAP2.3 (ERF72/EBP), SUB1A (Submergence1A), SUB1B (Submergence1B),
SUB1C (Submergence1C), SK1 (Snorkel1) and SK2 (Snorkel2) transcription factors (16, 17). ERF-VII coordinated waterlogging tolerance in wheat (18), maize (19), Arabidopsis (20-22), Taxodium (23) and Petunia (24).

\section{$\mathrm{N}$-end rule pathway (NERP) in plants}

$\mathrm{N}$-end rule pathway plays a significant role in plants to survive under waterlogging stress (25-27). In this pathway, RAP2.12 (ERF-VII) protein is attached with plasma membrane localized acyl-CoA binding protein1 and 2 (ACBP1 and ACBP2) (28) (Fig. 2). $R A P 2.12$ protein also interacts with cell membrane and cytosol located ACBPs (29). The terminal Met of RAP2.12 is removed by the enzyme methionine aminopeptidase (MetAP) when the second amino acid of this protein cysteine (cys) residue remains exposed (30). Cysteine sulfinic or sulfonic acid is formed by the oxidation of the N-terminal cysteine (ox-cys) residue with the presence of oxygen or nitric oxide (31). An arginyl residue (Arg) is added at the $\mathrm{N}$ terminus of the Oxidized cysteine by the enzyme arginine-tRNA protein transferases (ATEs) via a peptide bond (32). Arg signals a selective class of ubiquitin ligases proteolysis6 (PRT6) to polyubiquitinate for degradation of the polypeptide 


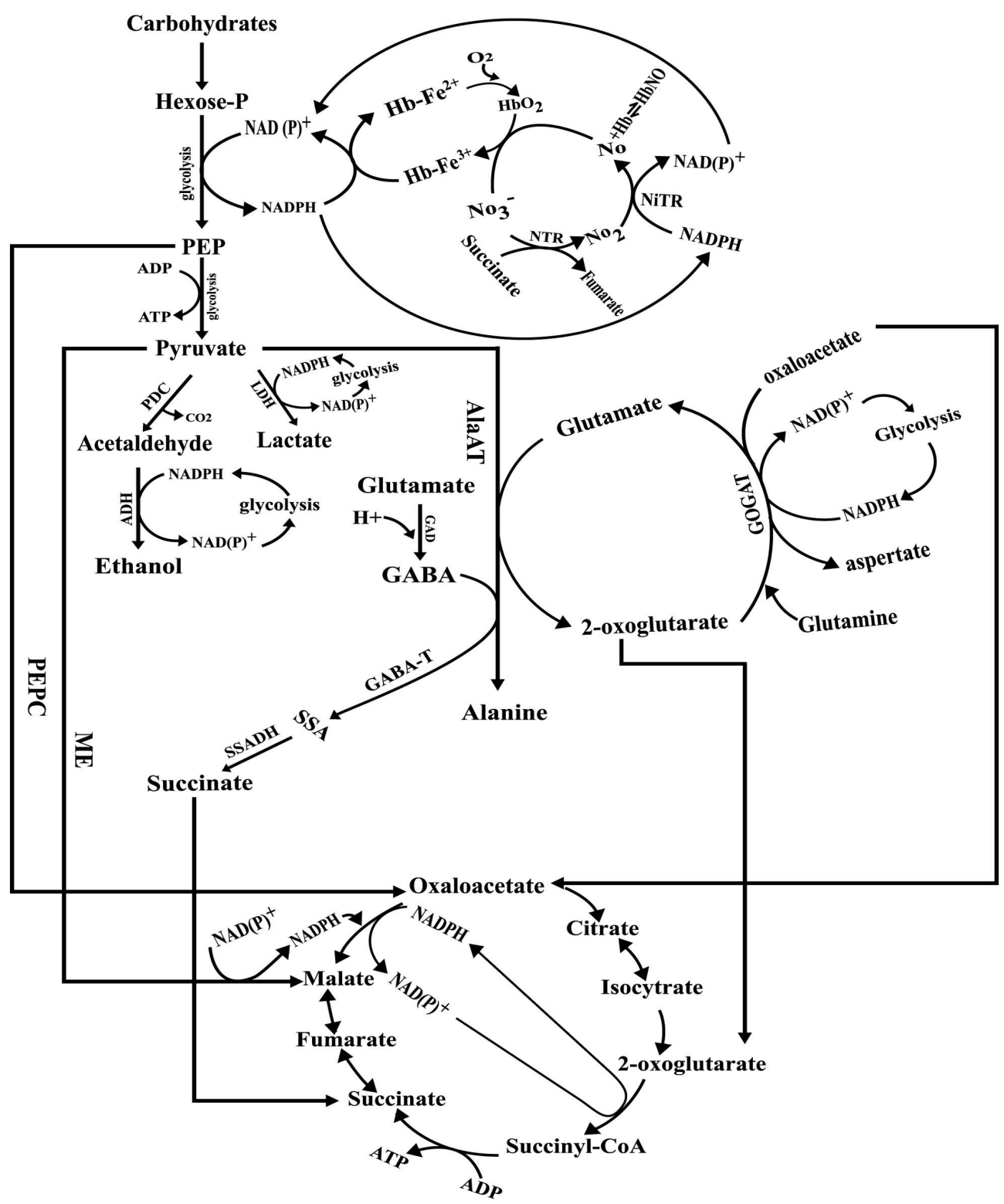

Fig. 3. Continuation of glycolysis and TCA cycle in plants using different biochemical and physiological pathways under waterlogged stress. Modified figure (16, 53, 62). ADH: Alcohol dehydrogenase; AlaAT: Alanine aminotransferase; GABA: Gama-aminobutyric acid; GABA-T: Gama-aminobutyric acid transaminase; GOGAT: Glutamine oxoglutarate aminotransferase; $\mathrm{Hb}-\mathrm{Fe}^{+2}$ : haemoglobins; $\mathrm{Hb}^{-\mathrm{Fe}^{+3}}$ : Methaemoglobin; HbNO: Nitroso-haemoglobin; $\mathrm{HbO}_{2}$ : Oxyhaemoglobin; LDH: Lactate dehydrogenase; ME: Malic enzyme; $\mathrm{NO}_{2}^{-}: \mathrm{Nitrite}^{-} \mathrm{NO}_{3}$ : Nitrate; PDC: Pyruvate decarboxylase; PEP: Phosphoenolpyruvate; PEPC: Phosphoenolpyruvate carboxylase; SSA: Succinic semialdehyde; SSADH: Succinic semialdehyde dehydrogenase.

through the $26 \mathrm{~S}$ proteasome $(33,34)$. This happened in both the cytosol and the nucleus (35). Thus, ERFVII proteins are degraded following the N-end rule pathway during aerobic conditions. On the other hand, plant cell cannot degrade ERF-VII during waterlogging or hypoxic stress due to the lack of oxygen and/or nitric oxide. Under hypoxic condition, non-degraded ERF-VII moves into the nucleus and takes part in the response of plant anaerobiosis (36). Though plant produces nitric oxide (NO) during the hypoxic stress, but the very rapid conversion of NO makes it nonfunctional to degrade ERF-VII protein. We will discuss the conversion of NO at the later stage of this paper under the heading of "Nonsymbiotic hemoglobin-nitric oxide homeostasis". Pre-adapted Arabidopsis plant to survive under waterlogging stress by producing ethylene-mediated NO-scavenger "Phytoglobin1", which reacts with NO and form NO-Phytoglobin1 complex (37). Thus NO temporarily loss their ability to degrade ERF-VII proteins under aerobic (no waterlogging stress) condition. In this mechanism, Arabidopsis produces a certain amount of ERF-VII before facing waterlogging stress, and produces fermentation genes just after the starting of waterlogging stress.

\section{Importance of the stoppage of NERP}

The ERF-VII transcription factor remains nondegraded during hypoxia for the lack of oxygen or nitric oxide (NO). This active ERF-VII enhances the activity of the first adaptive metabolic pathway in plants that is the anaerobic fermentation $(22,24)$. Overexpression of the ERF-VII transcription factors, HRE1, HRE2, RAP2.2 and RAP2.12 enhanced the alcohol dehydrogenase (ADH) activity only in 
hypoxia but not in normoxia condition (38). ERF-VII not only induces the alcohol dehydrogenase (ADH) genes but also induce pyruvate decarboxylase (PDC) (29). The function of both the PDC and $\mathrm{ADH}$ ultimately completes the ethanolic fermentation in tobacco under low oxygen stress (39).

Though most reports explained the activation of ethanolic fermentation by the ERF-VII transcription factor, its effect on lactate fermentation is not well described except in Arabidopsis (40). Thus, ERF-VII activates both the ethanolic and lactate fermentation during waterlogging stress, though there is a contradictory which one is activated earlier.

Under hypoxic stress, lactate dehydrogenase (LDH) and its product lactic acid are produced earlier than ethanol. This leads to acidification of cytosol and ethanol is produced to neutralize the cytosol $\mathrm{pH}$, which is first described (41) and later confirmed (42). We know this sequence of events as the DaviesRoberts hypothesis. Therefore, we may conclude that NERP activates LDH first than the PDC. Though, ethanol and lactic acid can be produced simultaneously in plants under hypoxic stress, depending on the species and the degree of $\mathrm{O}_{2}$ deficiency (43). Over expression of enzymes for alcohol and lactate enhances waterlogging tolerance in tobacco (44) and Brassica napus (45) respectively.

\section{Importance of lactic acid and ethanol}

Mitochondrial aerobic respiration stops by blocking the TCA (Tricarboxylic acid) cycle due to the lack of a terminal electron acceptor during the hypoxic condition. This leads to the generation of ATP dropped from 36 to 2 moles per mole of glucose metabolized by using glycolysis and fermentation (anaerobic respiration) (46). To meet up the shortage of this energy, plant accelerates the glycolysis for its oxygen independency that leads to the reduction of carbohydrate reserve (47). In the lactate fermentation, pyruvate is converted to lactate through $\mathrm{LDH}$, where NADPH is converted to NAD(P) (Fig. 3). On the other hand, pyruvate is converted to acetaldehyde through the PDC without conversion of $\mathrm{NADPH}$ to $\mathrm{NAD}(\mathrm{P})^{+}$in ethanolic fermentation. In the next step, acetaldehyde is converted to ethanol by the enzyme $\mathrm{ADH}$ and converts $\mathrm{NADPH}$ to $\mathrm{NAD}(\mathrm{P})^{+}$. Therefore, plants under hypoxia, continue oxygenindependent glycolysis and both the lactate and ethanolic fermentation continuously regenerate $\mathrm{NAD}(\mathrm{P})^{+}$and produces only 2 moles ATP instead of 38 moles (48).

\section{Demerits of lactic acid and ethanol}

Lactate fermentation is associated with cytosolic acidification, and most of the lactate is stored in the vacuole or released to the surrounding medium (42). The presence of unabated lactate might well cause cell death (49). If $\mathrm{pH}$ drops too much, the enzymes of the cell are denatured or precipitate, and the reactions may stop (50). In addition, proton accumulation $\left(\mathrm{H}^{+}\right)$is increased under the low level of cytosolic $\mathrm{pH}$, associated with $\mathrm{NADH}$ and $\mathrm{NADPH}$ or the hydrolysis of ATP (51). This happened for the lack of enough energy for the proper functioning of the $\mathrm{H}^{+}$ATPase enzyme under hypoxic condition (52). In general plant switch from lactate fermentation to ethanolic fermentation to save the cell as ethanol helps to increase the cellular pH (41). Unfortunately, ethanolic fermentation may also increase the cytosolic $\mathrm{pH}$, if the $\mathrm{CO}_{2}$ (release from the reaction of pyruvate to acetaldehyde) is not extrusion to the surrounding medium (42).

Ethanol generally diffuses to the extracellular medium, which leads to a considerable loss of carbon during hypoxia and poses no major problem (53). But excess ethanol hampers ion transport system in plant which is detrimental to plant cell (54). It also has detrimental effects on somatic cell division, protoplasts growth, and embryogenesis $(55,56)$.

\section{Nonsymbiotic hemoglobin-nitric oxide homeostasis}

The plant contains both symbiotic and nonsymbiotic hemoglobins. Symbiotic hemoglobins or leghemoglobins are found only in nodules for $\mathrm{N}_{2}$ fixation and nonsymbiotic hemoglobins are expressed in different parts and tissues by hypoxic stress for an oversupply of nutrients and are referred to as stress-induced hemoglobins. Nonsymbiotic hemoglobins are divided into two classes. Class 2 hemoglobins have similar properties with symbiotic hemoglobins to bind with oxygen but class 1 hemoglobins (presently known as phytoglobins) have distinct oxygen binding properties (57, 58). Overexpression of nonsymbiotic hemoglobin increases waterlogging tolerance in Arabidopsis (59, 60 ), cabbage (61) and maize (60).

There are two different nitrate reductase (NR) in the root, one in the cytosol (cNR) and the other attached to the plasma membrane and facing the apoplast (PM-NR). Plant cells produce nitric oxide (NO) by the cytosolic nitrate reductase (cNR) under hypoxic condition. Plasma membrane nitrate reductase (PM-NR) carry out the activities of cytosolic nitrate reductase (cNR), particularly during the night (62).

Methemoglobin $\left(\mathrm{Hb}-\mathrm{Fe}^{+3}\right)$ can be reduced to hemoglobins $\left(\mathrm{Hb}-\mathrm{Fe}^{+2}\right)$ via NADH-dependent reductases (63) (Fig. 3) to form $\mathrm{NAD}(\mathrm{P})^{+}$that will be used in glycolysis. NO reacts rapidly with oxyhemoglobin $\left(\mathrm{HbO}_{2}\right)$ forming nitrate $\left(\mathrm{NO}_{3}^{-}\right)$and methemoglobin $\left[\mathrm{Hb}\left(\mathrm{Fe}^{+3}\right)\right]$. Nitrate $\left(\mathrm{NO}_{3}{ }^{-}\right)$is reduced to nitrite $\left(\mathrm{NO}_{2}^{-}\right)$to form fumarate from succinate by using nitrate reductase. $\mathrm{NO}_{2}^{-}$is reduced $\mathrm{NO}$ by using nitrite reductase and the byproduct $\mathrm{NAD}(\mathrm{P})^{+}$is used in glycolysis (64). Nitroso-hemoglobin (NO-Hb) is formed in a plant cell to reduce the amount of the detrimental effect of NO by hemoglobins (65). As the formation of $\mathrm{NO}-\mathrm{Hb}$ is a reversible reaction, the single $\mathrm{NO}$ again reacts with $\mathrm{HbO}_{2}$ to form $\left[\mathrm{Hb}\left(\mathrm{Fe}^{+3}\right)\right]$ and $\mathrm{NO}_{3}$.

\section{Importance of nsHb/NO cycle}

This cycle provides $\mathrm{NAD}(\mathrm{P})^{+}$from two different steps. The first one is MetHb to $\mathrm{Hb}$, and the second is nitrite to nitric oxide. Therefore, the main advantage of this cycle is the alternative way to supply $\mathrm{NAD}(\mathrm{P})^{+}$for glycolysis rather than detrimental lactate and alcoholic fermentation. As this cycle contains more steps than the anaerobic fermentation, provides enough time for the plant to develop adventitious 
roots, which is necessary for long-term hypoxia survival (66). The half-life of NO in biological tissues is estimated to be <6s (67). This makes it highly reactive, directly with metal complexes and other radicals and indirectly as a reactive nitrogen oxide species with DNA, proteins, and lipids (68). Thus, $\mathrm{nsHb} / \mathrm{NO}$ indirectly helps to express ERF-VII genes in plants by reducing the amount of NO under hypoxic stress to run anaerobic fermentation. Under hypoxic condition, proton $\left(\mathrm{H}^{+}\right)$extrusion is limited because of the shortage of ATP, as a result, proton concentration becomes high in the cytosol. nsHb/NO uptakes the excess proton and used to produce $\mathrm{NAD}(\mathrm{P})^{+}$from $\mathrm{NADPH}$, that may help to reduce the cytosolic acidification.

The production of oxyhemoglobin $\left(\mathrm{HbO}_{2}\right)$ requires $\mathrm{O}_{2}$ to bind with hemoglobin. This nsHb/NO cycle may not provide enough oxyhemoglobin $\left(\mathrm{HbO}_{2}\right)$ to react with NO to recycle Methemoglobin $\left(\mathrm{Hb}-\mathrm{Fe}^{+3}\right)$ due to the limited supply of $\mathrm{O}_{2}$ under hypoxic stress. Thus, this cycle may not continuously supply enough $\mathrm{NAD}(\mathrm{P})^{+}$to run glycolysis.

\section{Alanine Aminotransferase pathway and TCA cycle}

Alanine aminotransferase (AlaAT) is a complex pathway, act as a survival mechanism in Lotus, Prunus, grapevine and Arabidopsis against waterlogging stress $(53,69,70,71)$. In this pathway, previously produced pyruvate from glycolysis reacts with glutamate (Glu) to form 2-oxoglutarate by alanine aminotransferase (AlaAT) (Fig. 3) (53). 2oxoglutarate reacts with glutamine to recycle glutamate by Glutamine Oxoglutarate Aminotransferase (GOGAT), where NADPH is converted to $\mathrm{NAD}(\mathrm{P})^{+}$. This $\mathrm{NAD}(\mathrm{P})^{+}$recycled at glycolysis for a continuous supply of pyruvate to convert alanine. The NADPH produced in glycolysis may be used again to convert glutamine to glutamate (72). Glutamate is converted to gamma-aminobutyric acid (GABA) by using cytosolic proton $\left(\mathrm{H}^{+}\right)$with the presence of glutamate decarboxylase (GAD) (Fig. 3). GABA reacts with pyruvate to form alanine and Succinic semialdehyde (SSA) by gamma-aminobutyric acid transaminase (GABA-T). SSA is converted to succinate by succinic semialdehyde dehydrogenase (SSADH), which is used in the TCA cycle. On the other hand, glutamate may reversibly react with oxoglutarate to form 2-oxoglutarate and aspartate by aspartate aminotransferase (AspAT) (Fig. 3). This 2oxoglutarate is used to produce succinyl-CoA by the enzyme 2-oxoglutarate dehydrogenase (OGDH) by using $\mathrm{NAD}(\mathrm{P})^{+}$to produce NADPH. Succinyl-CoA converts to succinate by using ADP to produce ATP under long term hypoxic stress. Phosphoenolpyruvate (PEP) from glycolysis is converted to oxaloacetate via phosphoenolpyruvate carboxylase (PEPC). This oxaloacetate is produced in the plants by using two enzymes named phosphoenolpyruvate carboxylase (PEPC) and aspartate aminotransferase (AspAT) from two different pathways. Oxaloacetate is converted to malate by malate dehydrogenase (MDH), where $\mathrm{NADPH}$ is recycled to $\mathrm{NAD}(\mathrm{P})^{+}$, which is used to the continuous biosynthesis of succinyl-CoA from 2oxoglutarate by OGDH. Then, malate is converted to fumarate and fumarate is converted to succinate for oxidative phosphorylation to produce ATP. Therefore, the presence of more pyruvate in the hypoxic plant cell, more ATP will be produced from the TCA cycle. Another source of pyruvate in a hypoxic plant cell is the conversion of malate to pyruvate by the malic enzyme (ME). Where NADPH is produced from $\mathrm{NAD}(\mathrm{P})^{+}$, this may be again used in the conversion of oxaloacetate to malate (53).

\section{Importance of alanine aminotransferase pathway}

Rapid and continuous conversion of pyruvate to alanine helps to continue the glycolysis pathway necessary for hypoxic ATP production (53). Excess accumulation of alanine is not harmful to plant cell as alanine production may balance the cytosolic $\mathrm{pH}$ under anoxic stress (73). Alanine aminotransferase pathway along with glutamate 2-oxoglutarate cycle provides $\mathrm{NAD}(\mathrm{P})^{+}$for glycolysis. Excess cellular proton $\left(\mathrm{H}^{+}\right)$is indirectly consumed by this pathway during the conversion of glutamate to GABA. Alanine aminotransferase pathway indirectly produces the 2oxoglutarate and oxaloacetate required for the TCA cycle. Thus, conversion of pyruvate to alanine produces not a single harmful product in plants under oxygen limiting stress, and it contributes to the reduction of cellular $\mathrm{pH}$, provides $\mathrm{NAD}(\mathrm{P})^{+}$for glycolysis, consumes excess proton $\left(\mathrm{H}^{+}\right)$and provides necessary products for the continuation of TCA cycle. Therefore, triggering the gene responsible for alanine aminotransferase may account for the ability to survive under flooding stress.

\section{Modified TCA cycle or glyoxylate cycle}

The tricarboxylic acid (TCA) cycle provides necessary energy (ATP) for growth and development in plants (74). Waterlogging stress noticeably hampers this necessary pathway as direct conversion of pyruvate to acetyl-CoA is restricted due to the non-functional activity of the pyruvate dehydrogenase enzymatic complex (75). In this situation, plants search for an alternative source of energy along with glycolysis and eventually starts the modified TCA cycle or glyoxylate cycle. The conversion of pyruvate to acetyl-CoA occurs in mitochondria and glyoxysome with three enzymes (76). Pyruvate decarboxylase (PDC) and mitochondrial aldehyde dehydrogenase (mALDH) used in mitochondria and acetyl-CoA synthetase (ACS) used in glyoxysome (Fig. 4). Pyruvate is transported to mitochondria from the cytosol and converted to acetaldehyde by PDC. Acetaldehyde is further converted to acetate by mALDH. Finally, acetate is transported from mitochondria to glyoxysome and converted to acetyl-CoA by ACS (77). Acetyl-CoA reacts with glyoxylate to form malate in the presence of malate synthase. Malate is converted to oxaloacetate that reacts with acetyl-CoA to form citrate. Citrate is converted to isocitrate and finally, succinate is produced from isocitrate by using isocitrate lyase. Finally, succinate reaches to mitochondria from glyoxysome for the production of ATP through oxidative phosphorylation. Generally, isocitrate is converted to succinate through mitochondrial TCA cycle by three consecutive steps (Fig. 3) but in the glyoxylate cycle needs only one step. That reduces the carbon uses at low oxygen stress in plants like rice (78). 


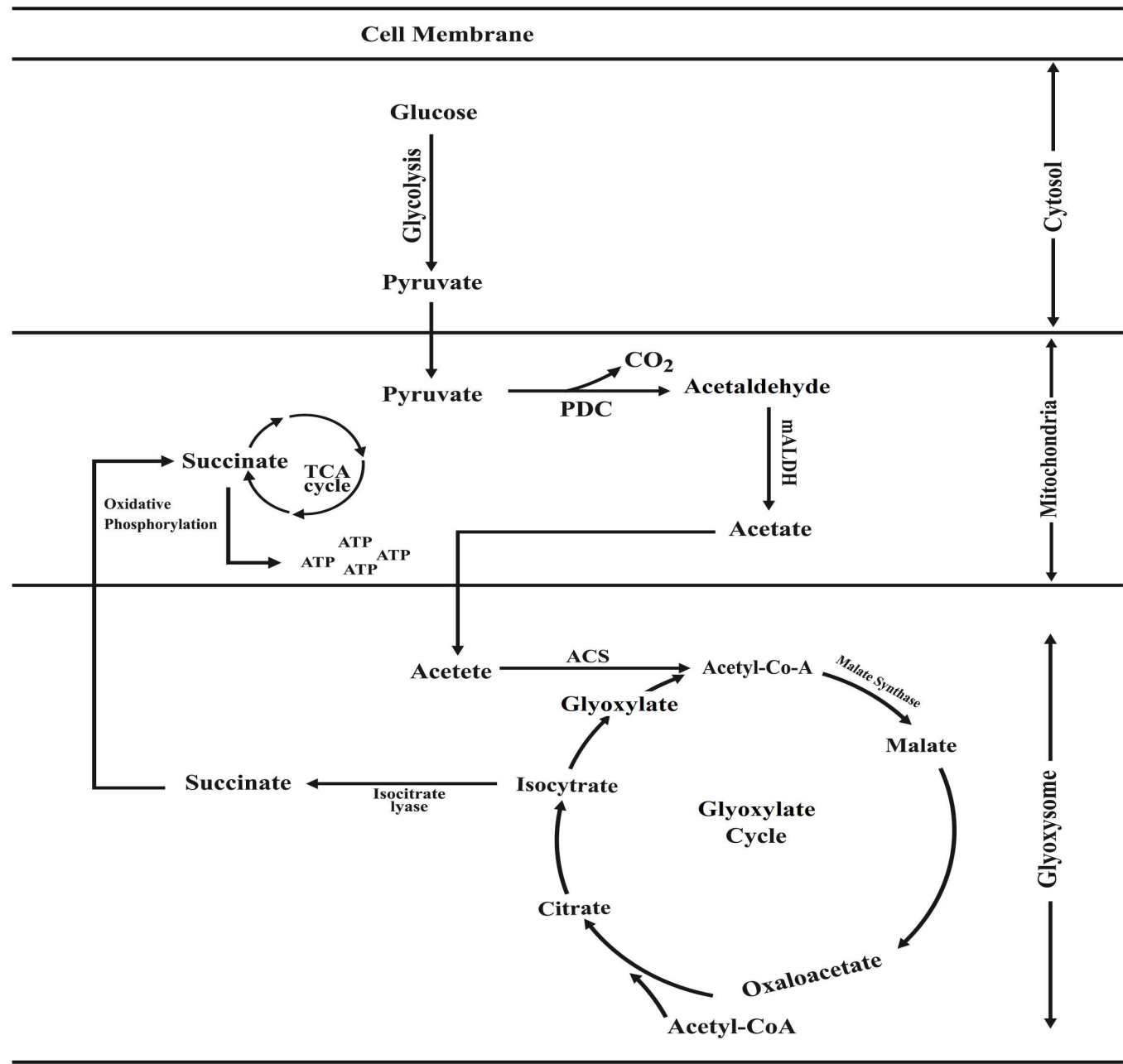

Fig. 4. Alternate TCA cycle (Glyoxylate cycle) in plants under low oxygen stress. Modified figure (77). ACS: ACC synthase; PDC: Pyruvate decarboxylase.

\section{Calcium signaling and functioning in plants under hypoxic stress}

Hypoxia increases cytoplasmic $\mathrm{Ca}^{2+}$ concentration in plants (79-81). The increased hypoxic $\mathrm{Ca}^{2+}$ concentration significantly influences different metabolic pathways, enzymatic functions, and ROS homeostasisplants. For example, cucumber plant maintains higher $\mathrm{Ca}^{2+}$ concentration under low oxygen stress, which prompts antioxidant enzymes, decreases ROS production, increases the number of mitochondria, plasma membrane proton ATPase (PM $\mathrm{H}^{+}$-ATPase), tonoplast $\mathrm{H}^{+}$-ATPase, tonoplast proton pyrophosphatase (tonoplast $\mathrm{H}^{+}$-Ppase), different glycolytic and TCA cycle enzymes that helps ATP homeostasis (82). Modulation of glutamate decarboxylase (GAD) for the conversion of glutamate to GABA in Arabidopsis thaliana is also controlled by cytoplasmic $\mathrm{Ca}^{2+}$ concentration (83). Anoxic condition in plants quickly raises $\mathrm{Ca}^{2+}$ concentration and induces ADH activity (84). It also involved in antioxidant production and nitrogen metabolism in muskmelon (85). Formation of ammonium from nitrate enhances hypoxia tolerance in Cucumis sativus by incorporation of ammonium into amino acids and proteins (86). Plants can reduce ammonium toxicity by converting it into amino acids or by reserving into the vacuole (87).

\section{Aerenchyma formation through the ethylene- calcium interaction}

Ethylene induced calcium release mechanism under hypoxic stress has been described (88) and shown in Fig. 5. Ethylene activates plasma membrane G protein and produces plasma membrane phospholipase C (PLC). PLC hydrolyzes plasma membrane phosphatidyl inositol 4,5 biphosphate (PIP2) and produces 1,2-diacylglycerol (DAG) and cytosolic Inositol 1,4,5 triphosphate (IP3). IP3 activates the $\mathrm{Ca}^{2+}$ channel in the endoplasmic reticulum (ER) or tonoplast, which allows the release of $\mathrm{Ca}^{2+}$ to the cytosol and increases cytosolic $\mathrm{Ca}^{2+}$ concentration within plants' cell. In combination with DAG, IP3 activates cytosolic Protein Kinase C (PKC), which adds phosphates to the cellulases, xylanases etc., enzymes to make it active. Both DAG and $\mathrm{Ca}^{2+}$ can directly activate PKC independently. Therefore, this protein activation procedure through ethylene-calcium interaction may be considered as the basis of cellular homeostasis under hypoxic stress. These specific enzymes activate hypoxiarelated genes, which allows programmed cell death (PCD) for aerenchyma formation. For example, protein phosphorylation activates the cell wall degrading cellulases, xylanases, xyloglucan endotransglucosylase hydrolases (XTHs) etc., for 


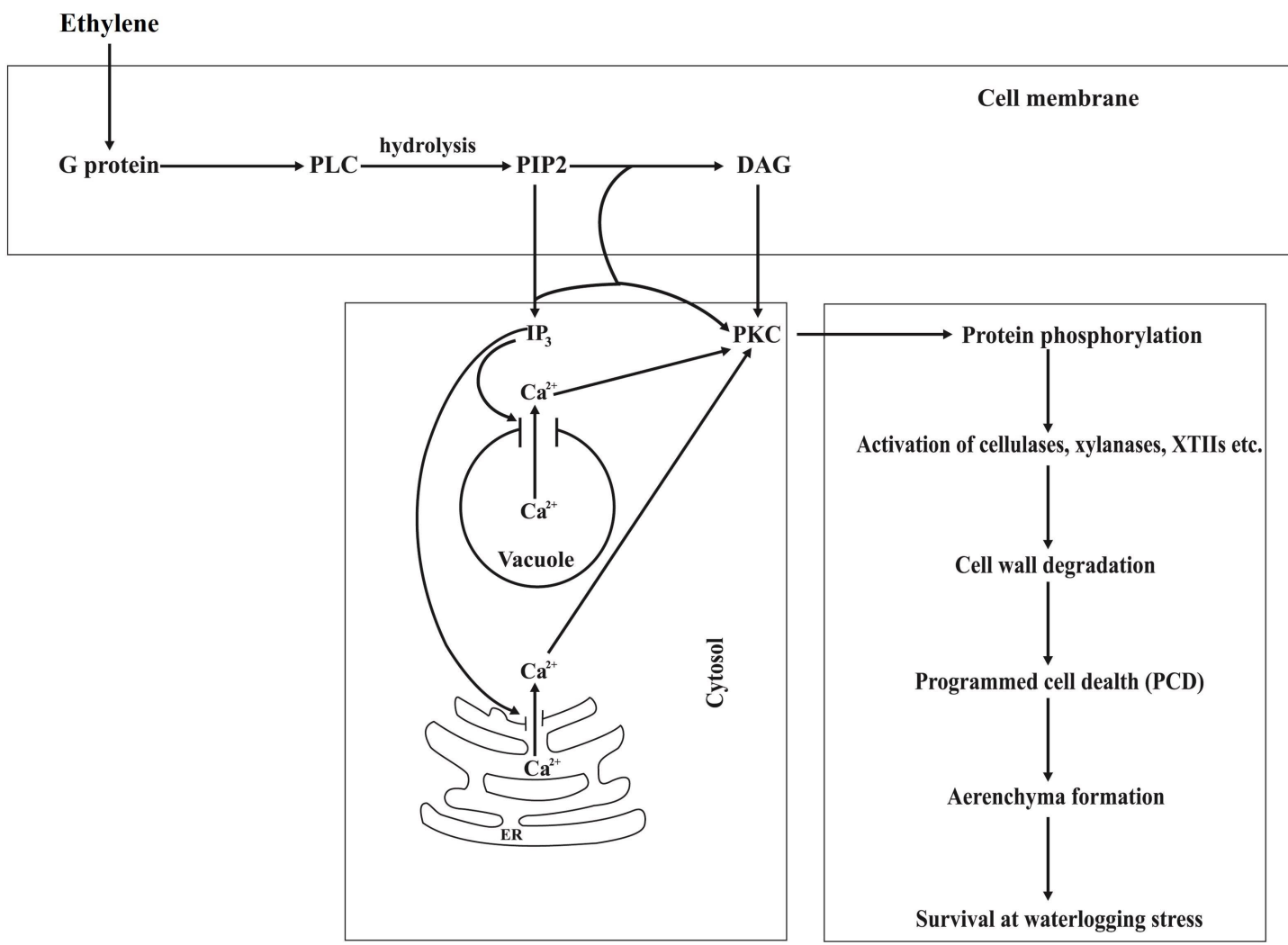

Fig. 5. Ethylene-mediated aerenchyma formation in plants under waterlogged stress. ER: Endoplasmic reticulum; DAG: 1,2-diacylglycerol; IP3: Inositol 1,4,5 triphosphate; PKC: Protein kinase C; PIP2: Phosphatidyl inositol 4,5 biphosphate; PLC: Plasmamembrane Phospholipase C; XTHs: Xyloglucan endotransglucosylase hydrolases

Table 1. Different signaling and physiological pathways in plants under waterlogging stress

\begin{tabular}{|c|c|c|c|}
\hline Sl no. & Name of pathways & objectives & References \\
\hline 1 & Ethylene biosynthesis & Produce ethylene signaling in plants & (7) \\
\hline 2 & Ethylene signaling & Expression of ERF-VII genes & (4) \\
\hline 3 & $\begin{array}{l}\text { Disruption of N-end rule } \\
\text { pathway }\end{array}$ & $\begin{array}{l}\text { Stops the breakdown of } E R F-V I I \text {, thus helping to express waterlogging specific } \\
\text { lactate and ethanolic genes }\end{array}$ & $(29,38,40)$ \\
\hline 4 & $\begin{array}{l}\text { Lactate and ethanolic } \\
\text { fermentation }\end{array}$ & Continuous supply of $\mathrm{NAD}(\mathrm{P})^{+}$to run glycolysis & (48) \\
\hline 5 & $\begin{array}{l}\text { Nonsymbiotic haemoglobin- } \\
\text { nitric oxide homeostasis }\end{array}$ & $\begin{array}{l}\text { Alternate source of } \mathrm{NAD}(\mathrm{P})^{+} \text {to run glycolysis due to detrimental effects of } \\
\text { lactate and ethanolic fermentation }\end{array}$ & (66) \\
\hline 6 & $\begin{array}{l}\text { Alanine aminotransferase } \\
\text { pathway }\end{array}$ & $\begin{array}{l}\text { 1. Indirectly helps to supply } \mathrm{NAD}(\mathrm{P})^{+} \text {necessary for glycolysis } \\
\text { 2. indirectly produces } 2 \text {-oxoglutarate and oxaloacetate that are required for } \\
\text { TCA cycle }\end{array}$ & (72) \\
\hline 7 & TCA cycle & ATP production & (53) \\
\hline 8 & Glyoxylate cycle & $\begin{array}{l}\text { Skipping of two steps comparing with mitochondrial TCA cycle to avoid the } \\
\text { loss of two carbon molecules, which indirectly helps to store ATP under } \\
\text { hyoxic stress }\end{array}$ & (77) \\
\hline 9 & Calcium signaling & $\begin{array}{l}\text { Increases number of mitochondria, prompts antioxidant enzymes, decreases } \\
\text { ROS production, increases plasma membrane proton ATPase (PM H } \mathrm{H}^{+} \text {-ATPase), } \\
\text { tonoplast } \mathrm{H}^{+} \text {-ATPase, tonoplast proton pyrophosphatase (tonoplast } \mathrm{H}^{+} \text {-Ppase), } \\
\text { increases different glycolytic and TCA cycle enzymes which ultimately helps } \\
\text { ATP homeostasis }\end{array}$ & $(82,85)$ \\
\hline 10 & Ascorbate-glutathione cycle & Remove ROS from plant cells & (104) \\
\hline
\end{tabular}

programmed cell death (PCD) in plants under hypoxic stress $(4,89)$.

\section{RHO-like small G protein (ROP) signaling pathway for activation of anoxic $\mathrm{ADH}$}

Oxygen deprivation starts the ROP GTPase signal transduction pathway necessary for activating DPI (diphenylene iodonium chloride)-sensitive NADPH oxidase. This ROP GTPase signaling enhances defense responses and plants developmental processes, whereas abscisic acid-induced closure of leaf stomata is the effect of inactivation of ROP signaling (90). Free cytoplasmic $\mathrm{Ca}^{2+}$ binds with plasma membrane DPIsensitive NADPH oxidase or inner mitochondrial membrane DPI-sensitive NADPH oxidase (91). Both the ROP signal transduction pathway and $\mathrm{Ca}^{2+}$ binding with NADPH oxidase finally activate NADPH oxidase. As a result, concentration of $\mathrm{H}_{2} \mathrm{O}_{2}$ (hydrogen peroxide) increases, that's acts as a secondary messenger for transmitting the information of 
oxygen deprivation by expressing ADH (92). RopGAP4 (Rop (RHO-like small G protein of plants) guanosine triphosphatase activating protein 4) is a negative regulator of a RopGTPase, which promotes hydrolysis of GTP. Enhanced RopGAP4 expression down regulates RopGTPase and consequently down regulates $\mathrm{H}_{2} \mathrm{O}_{2}$ production. RopGAP4 expression is also controlled by the activation of NADPH oxidase (93). Perhaps the expression of RopGAP4 inside the plant cell shows the excess presence of ROS like $\mathrm{H}_{2} \mathrm{O}_{2}$ and toxic alcohol. Therefore, RopGAP4 plays a key role in maintaining the balanced volume of $\mathrm{H}_{2} \mathrm{O}_{2}$ and $\mathrm{ADH}$ to adjust the oxygen-deprived tissue inside the plant cell.

\section{ROS and RNS production during low oxygen stress}

Oxygen deprived plant tissues change several internal cellular processes like lipid content and composition, membrane fluidity, cytoplasmic acidosis, changes in the patterns of protein synthesis, and a decrease in the adenylate energy charge (9496). Most of these changes are responsible for ROS production, which favors lipid degradation by peroxidation of lipids (94).

Different enzymes like plant homolog of the mammalian respiratory burst NADPH oxidase (RBOH), are responsible for systemic signaling under various environmental stress in plants by generating and amplifying ROS (97). There are different plant cellular organelles, but some maintain highly oxidizing metabolic activity. Chloroplasts, mitochondria and microbodies maintain their metabolism by transporting electron, which is also responsible for ROS production in plants to contribute an oxidative burst during abiotic stress (98). Plants stimulate $\mathrm{H}_{2} \mathrm{O}_{2}$ production as a key regulator for different responses under hypoxic stress (99). There are two main mechanisms available for $\mathrm{H}_{2} \mathrm{O}_{2}$ production under hypoxic stress. These are the consequence of the breakdown of the mitochondrial electron transport chain (m-ETC) and DPI-sensitive activation of NADPH oxidase through Rop-signaling. Under hypoxic stress, complex III of m-ETC produces superoxide $\left(\mathrm{O}_{2}^{-}\right)$anion by increasing the abundance of the partially reduced ubisemiquinone anion. This $\mathrm{O}_{2}^{-}$is rapidly converted to $\mathrm{H}_{2} \mathrm{O}_{2}$ through spontaneous dismutation or by a reaction with superoxide dismutase (SOD) (100). $\mathrm{H}_{2} \mathrm{O}_{2}$ may also be produced by potassium cyanide (KCN) and sodium nitroprusside (SNP) which are considered as the inhibitors of respiration (101). These are evidences for the increased formation of antioxidants, superoxide dismutase, peroxidase and catalase in pepper plants under waterlogging stress (102).

Plants Produce NO under oxygen deprivation stress by non-enzymatically from exogenous nitrite and enzymatically via cytosolic nitrate reductase and plasma membrane-bound nitrite-NO reductase (67). $\mathrm{NO}$ can react either with $\mathrm{O}_{2}$ or $\mathrm{O}_{2}^{-}$to produce $\mathrm{NO}_{2}$ (nitrogen dioxide), $\mathrm{N}_{2} \mathrm{O}_{2}$ (nitrous oxide), and $\mathrm{ONOO}^{-}$ (peroxynitrite). These have harmful consequences and signaling roles in biological systems (68). NO can easily be transported within the cell because of its capability to freely penetrate into the lipid bilayer. Its chemical properties make this gas as a good candidate for a signaling molecule. NO has a short half-life (in order of seconds) because of its free radical nature (one unpaired electron) (103).

\section{Removal of hydrogen peroxide through ascorbate- glutathione cycle}

A standard model for the $\mathrm{H}_{2} \mathrm{O}_{2}$ removal mechanism in the plant cell had been described (104). Ascorbate peroxidase (APX) uses two molecules of ascorbate (AA) to reduce $\mathrm{H}_{2} \mathrm{O}_{2}$ to water, with the concomitant production of two molecules of monodehydroascorbate (MDHA) (104). Monodehydroascorbate (MDHA) is enzymatically converted to ascorbate (AA) by monodehydroascorbate reductase (MDHAR) and nonenzymatically to dehydroascorbate (DHA). Dehydroascorbate is also reduced to ascorbate by the enzyme dehydroascorbate reductase (DHAR), with the concomitant reduction of glutathione disulfide (GSSG) to glutathione (GSH). We know these series of sequential steps as the ascorbate-glutathione cycle, which is responsible for the removal of harmful $\mathrm{H}_{2} \mathrm{O}_{2}$ from the plant cell.

\section{Conclusion}

Survival ability of plants under waterlogging stress depends on several consecutive signaling and physiological pathways that are involved in waterlogging stress tolerance (Table 1). All these pathways make a complex tolerance mechanism in plants at the oxygen deprivation condition. This study presents a simple illustration of interconnection with various signaling and physiological pathways under waterlogging stress condition, through which the plant tries to survive. Though increased survival ability against waterlogging stress was found in plants by manipulating the specific gene but still complete satisfactory tolerance was not found yet. Therefore, the correlation between the specific gene and pathway with other genes or pathways is to be considered efficiently to get a desirable waterlogging tolerant crop plant. Plants' responses to waterlogging stress have been progressively discovered from the fermentation to current findings. But, still we are very far away to control the highly multigenic waterlogging stress in plants. The future exciting and thrilling discoveries certainly help plant scientists at mitigating the harmful effects of waterlogging stress in the economy of farmers.

\section{Acknowledgements}

The authors are thankful to the Basic and Applied Research on Jute Project, Bangladesh Jute Research Institute, Dhaka 1207, Bangladesh for providing all the necessary facilities.

\section{Disclosure statement}

No potential conflict of interest was reported by the authors. 


\section{Author Contributions}

Conceptualization by KKB; Writing - original draft preparation by KKB and MZT; Writing - review and editing by MSI.

\section{References}

1. Cramer GR, Urano K, Delrot S, Pezzotti M, Shinozaki K. Effects of abiotic stress on plants: a systems biology perspective. BMC Plant Biol. 2011;11(163):1-14. https://doi.org/10.1186/1471-222911-163

2. Patel PK, Singh AK, Tripathi N, Yadav D, Hemantaranjan A. Flooding: Abiotic constraint limiting vegetable productivity. Adv Plants Agri Res 2014;1(3):96-103. https://doi.org/10.15406/apar.2014.01.00016

3. Rivera-Contreras, IK, Zamora-Hernández T, Huerta-Heredia AA, Capataz-Tafur J, Barrera-Figueroa BE, Juntawong P, PeñaCastro JM. Transcriptomic analysis of submergence-tolerant and sensitive Brachypodium distachyon ecotypes reveals oxidative stress as a major tolerance factor. Sci Rep. 2016; 6:27686. https://doi.org/10.1038/srep27686

4. Sasidharan R, Voesenek LACJ. Ethylene-mediated acclimations to flooding Stress. Plant Physiol. 2015;169(1):3-12. https://doi.org/10.1104/pp.15.00387

5. Yang SF, Hoffman NE. Ethylene biosynthesis and its regulation in higher plants. Annu Rev Plant Physiol. 1984;35:155-89. https://doi.org/10.1146/annurev.pp.35.060184.001103

6. Jackson MB. Ethylene and responses of plants to soil waterlogging and submergence. Annu Rev Plant Biol. 1985;36(1):145-74.

https://doi.org/10.1146/annurev.pp.36.060185.001045

7. Ju C, Van de Poel B, Cooper ED, James H, Thierer JH, Gibbons TR, Delwiche CF, Chang C. Conservation of ethylene as a plant hormone over 450 million years of evolution. Nat Plants. 2015; 1:14004. https://doi.org/10.1038/nplants.2014.4

8. Chen Y, Randlett MD, Findell JL, Schaller GE. Localization of the ethylene receptor ETR1 to the endoplasmic reticulum of Arabidopsis. J Biol Chem. 2002;277(22):19861-66. https://doi.org/10.1074/jbc.M201286200

9. Grefen C, Stadele K, Ruzicka K, Obrdlik P, Harter K, Horak J. Subcellular localization and In Vivo interactions of the Arabidopsis thaliana ethylene receptor family members. Mol Plant. 2008;1(2):308-20. https://doi.org/10.1093/mp/ssm015

10. Bisson MMA, Bleckmann A, Allekotte S, Groth G. EIN2, the central regulator of ethylene signalling, is localized at the ER membrane where it interacts with the ethylene receptor ETR1. Biochem Journal. 2009;424(1):1-6. https://doi.org/10.1042/BJ20091102

11. Dong C, Rivarola M, Resnick JS, Maggin BD, Chang C. Subcellular co-localization of Arabidopsis RTE1 and ETR1 supports a regulatory role for RTE1 in ETR1 ethylene signaling. Plant J. 2008;53(2):275-86. https://doi.org/10.1111/j.1365313X.2007.03339.X

12. Xie C, Zhangy J, Zhouy H, Li J, Zhang Z, Wang D, Chen S. Serine/ threonine kinase activity in the putative histidine kinase-like ethylene receptor NTHK1 from tobacco. Plant J. 2003;33(2):38593. https://doi.org/10.1046/j.1365-313X.2003.01631.x

13. Ju C, Chang $\mathrm{C}$. Advances in ethylene signaling: protein complexes at the endoplasmic reticulum membrane. AoB Plants 2012; pls031. https://doi.org/10.1093/aobpla/pls031

14. Potuschak T, Lechner E, Parmentier Y, Yanagisawa S, Grava S, Koncz C, Genschik P. EIN3-dependent regulation of plant ethylene hormone signaling by two Arabidopsis $F$ Box proteins: EBF1 and EBF2. Cell. 2003;115(6):679-89. https://doi.org/10.1016/S0092-8674(03)00968-1

15. Song L, Liu D. Ethylene and plant responses to phosphate deficiency. Front Plant Sci. 2015;6:796. https://doi.org/10.3389/fpls.2015.00796

16. Bailey-Serres J, Fukao T, Gibbs DJ, Holdsworth MJ, Lee SC, Licausi F, Perata P, Voesenek LACJ, Van Dongen JT. Making sense of low oxygen sensing. Trends Plant Sci. 2012;17(3):12938. https://doi.org/10.1016/j.tplants.2011.12.004
17. Nakano T, Suzuki K, Fujimura T, Shinshi H. Genome-wide analysis of the ERF gene family in Arabidopsis and Rice. Plant $\begin{array}{ll}\text { Physiol. } & \text { 2006; 140(2):411-32. }\end{array}$ https://doi.org/10.1104/pp.105.073783

18. Wei X, Xu H, Rong W, Ye X, Zhang Z. Constitutive expression of a stabilized transcription factor ERFVII enhances waterlogging tolerance in wheat without penalizing grain yield. Plant Cell Environ. 2019; 42(5):1471-85. https://doi.org/10.1111/pce.13505

19. Yu F, Liang K, Fang T, Zhao H, Han X, Cai M, Qiu F. A group VII ethylene response factor gene, ZmEREB180, coordinates waterlogging tolerance in maize seedlings. Plant Biotechnol J. 2019; (Epub ahead of print). https://doi.org/10.1111/pbi.13140

20. Eysholdt-Derzso E, Sauter M. Hypoxia and the group VII ethylene response transcription factor HRE2 promote adventitious root elongation in Arabidopsis. Plant Biol. 2018; 1:103-08. http://dx.doi.org/10.1111/plb.12873

21. Giuntoli B, Perata P. Group VII Ethylene Response Factors in Arabidopsis: Regulation and Physiological Roles. Plant Physiol. 2018;176(2):1143-55. https://doi.org/10.1104/pp.17.01225

22. Gil-Monreal M, Giuntoli B, Zabalza A, Licausi F, Royuela M. 2019. ERF-VII transcription factors induce ethanol fermentation in response to amino acid biosynthesis-inhibiting herbicides. J Exp Bot. 2019;70(20):5839-51 https://doi.org/10.1093/jxb/erz355

23. Fan W, Yang Y, Wang Z, Yin Y, Yu C, Shi Q, Guo J, Xuan L, Hua J. Molecular cloning and expression analysis of three ThERF involved in the response to waterlogging stress of Taxodium 'Zhongshanshan406', and subcellular localization of the gene $\begin{array}{ll}\text { products. } & \text { 2018;12(6):e4434. }\end{array}$ http://dx.doi.org/10.7717/peerj.4434

24. Yin D, Sun D, Han Z, Ni D, Norri A, Jiang C. PhERF2, an ethylene-responsive element binding factor, plays an essential role in waterlogging tolerance of Petunia. Hort Res. 2019; 6(1):83. https://doi.org/10.1038/s41438-019-0165-Z

25. Gibbs DJ, Tedds HM, Labandera A, Bailey M, White MD, Hartman S, Sprigg C, Mogg SL, Osborne R, Dambire C, Boeckx T, Paling Z, Voesenek LACJ, Flashman E, Holdsworth MJ. Oxygen-dependent proteolysis regulates the stability of angiosperm polycomb repressive complex 2 subunit VERNALIZATION 2. Nat Commun. 2018;9(1):5438. https://doi.org/10.1038/s41467-018-07875-7

26. Chen M, Zhu F, Wang F, Ye N, Gao B, Chen X, Zhao S, Fan T, Cao Y, Liu T, Su Z, Xie L, Hu Q, Wu H, Xiao S, Zhang J, Liu Y. Alternative splicing and translation play important roles in hypoxic germination in rice. J Exp Bot. 2018;70(3):817-33. https://doi.org/10.1093/jxb/ery393

27. Lin C, Chao Y, Chen W, Ho H, Chou M, Li Y, Wu Y, Yang H, Hsieh $\mathrm{H}$, Lin $\mathrm{C}$, Wu F, Chou S, Jen $\mathrm{H}$, Huang Y, Irene D, Wu W, Wu J, Gibbs DJ, Ho M, Shih M. Regulatory cascade involving transcriptional and N-end rule pathways in rice under submergence. $\quad$ PNAS. 2019;116(8):201818507. https://doi.org/10.1073/pnas.1818507116

28. Licausi F, M Kosmacz, Weits DA, Giuntoli B, Giorgi FM, Voesenek LACJ, Perata P, Van Dongen JT. Oxygen sensing in plants is mediated by an N-end rule pathway for protein destabilization. $\quad$ Nature. 2011;479(7373):419-23. https://doi.org/10.1038/nature10536

29. Licausi F. Molecular elements of low-oxygen signaling in plants. $\quad$ Physiol. $\quad$ Plant. 2013;148(1):1-8. https://doi.org/10.1111/ppl.12011

30. Liao, Y, Jeng J, Wang C, Wang S, Chang S. Removal of Nterminal methionine from recombinant proteins by engineered E. coli methionine aminopeptidase. Protein Sci. 2004;13(7):1802-10. https://doi.org/10.1110/ps.04679104

31. Kwon YT, Kashina AS, Davydov IV, Hu R, An JY, Seo JW, Du F. A Varshavsky, An essential role of N-terminal arginylation in cardiovascular development. Science. 2002;297(5578):6-99. https://doi.org/10.1126/science.1069531

32. 32. Graciet E, Mesiti F, Wellmer F. Structure and evolutionary conservation of the plant N-end rule pathway. Plant J. 2010;61(5):741-51. $\quad$ https://doi.org/10.1111/j.1365313X.2009.04099.X

33. Voges D, Zwickl P, Baumeister W. The 26S Proteasome: A molecular machine designed for controlled proteolysis. Annu 
Rev

Biochem.

1999,68:1015-68

https://doi.org/10.1146/annurev.biochem.68.1.1015

34. Garzon M, Eifler K, Faust A, Scheel H, Hofmann K, Koncz C, Yephremov A, Bachmair A. PRT6/At5g02310 encodes an Arabidopsis ubiquitin ligase of the N-end rule pathway with arginine specificity and is not the CER3 locus. FEBS Lett. 2007; 581(17):3189-96. https://doi.org/10.1016/j.febslet.2007.06.005

35. Vallon U, Kull U. Localization of proteasomes in plant cells. Protoplasma. https://doi.org/10.1007/BF01403684

1994;182(1-2):15-18.

36. Kosmacz M, Parlanti S, Schwarzländer M, Kragler F, Licausi F, Van Dongen JT. The stability and nuclear localization of the transcription factor RAP2.12 are dynamically regulated by oxygen concentration. Plant Cell Environ. 2015;38(6):1094-03. https://doi.org/10.1111/pce.12493

37. Hartman S, Liu Z, van Veen H, Vicente J, Reinen E, Martopawiro S, et al. Ethylene-mediated nitric oxide depletion pre-adapts plants to hypoxia stress. Nat Commun. 2019; 10:4020. https://doi.org/10.1038/s41467-019-12045-4

38. Hess N, Klode M, Anders M, Sauter M. The hypoxia responsive transcription factor genes ERF71/HRE2 and ERF73/HRE1 of Arabidopsis are differentially regulated by ethylene. Physiol Plant. 2011;143(1):41-49. $\quad$ https://doi.org/10.1111/j.13993054.2011.01486.x

39. Tan X, Zwiazek JJ. Stable expression of aquaporins and hypoxia-responsive genes in adventitious roots are linked to maintaining hydraulic conductance in tobacco (Nicotiana tabacum) exposed to root hypoxia. PLOS One 2019; 14(2):e0212059. https://doi.org/10.1371/journal.pone.0212059

40. Paul MV, Iyer S, Amerhauser C, Lehmann M, Van Dongen JT, Geigenberger P. Oxygen sensing via the ethylene response transcription factor RAP2.12 affects plant metabolism and performance under both normoxia and hypoxia. Plant Physiol. 2016;172(1):141-53. https://doi.org/10.1104/pp.16.00460

41. Davies DD, Grego S, Kenworthy P. The control of the production of lactate and ethanol by higher Plants. Planta. 1974; 118(4):297-310. https://doi.org/10.1007/BF00385580

42. Roberts JKM, Hooks MA, Miaullis AP, Edwards S, Webster C. Contribution of malate and amino acid metabolism to cytoplasmic $\mathrm{pH}$ regulation in hypoxic maize root tips studied using nuclear magnetic resonance spectroscopy. Plant Physiol. 1992; 98(2):480-87. https://doi.org/10.1104/pp.98.2.480

43. Ricard B, Couée I, Raymond P, Saglio PH, Saint-Ges V, Pradet A. Plant metabolism under hypoxia and anoxia. Plant Physiol. Biochem. 1994; 32(1):1-10

44. Pan D, Wang G, Wang T, Jia Z, Guo Z, Zhang J. AdRAP2.3, a Novel Ethylene Response Factor VII from Actinidia deliciosa, Enhances Waterlogging Resistance in Transgenic Tobacco through Improving Expression Levels of PDC and ADH Genes. $\begin{array}{llll}\text { Int } & \text { Mol } & \text { Sci. } & \text { 2019;20(5):1189. }\end{array}$ https://doi.org/10.3390/ijms20051189

45. Xu B, Xie L, Cheng Y, Lu G, Zheng P, Zhang X. Cloning of Lactate dehydrogenase Gene and Effect on the Waterlogging Tolerance of Brassica napus L. Adv J Food Sci Tech. 2012;4(5):332-36

46. Das A, Uchimiya $H$. Oxygen stress and adaptation of a semiaquatic plant: rice (Oryza sativa). J Plant Res. 2002;115(5):31520. https://doi.org/10.1007/s10265-002-0043-9

47. Ren C, Kong C, Yan K, Zhang H, Luo Y, Xie Z. Elucidation of the molecular responses to waterlogging in Sesbania cannabina roots by transcriptome profling. Sci Rep. 2017;7:9256. https://doi.org/10.1038/s41598-017-07740-5

48. Parent C, Capelli N, Berger A, Crevecoeur M, Dat JF. An Overview of plant responses to soil waterlogging. Plant Stress. 2008; 2:20-27

49. Xia J, Saglio PH. Lactic acid efflux as a mechanism of hypoxic acclimation of maize root tips to anoxia. Plant Physiol. 1992; 100(1):40-46. https://doi.org/10.1104/pp.100.1.40

50. Wiebold WJ. Crop plant responses to flooding. Insect pest \& crop management newsletter, University of Missouri. https://ipm.missouri.edu/IPCM/2015/6/Crop-Plant-Response-toFlooding/ (accessed 10 November 2019). 2015; 25:6-7

51. Gout E, Boisson A, Aubert S, Douce R, Bligny R. Origin of the cytoplasmic pH changes during anaerobic stress in higher plant cells. carbon-13 and phosphorous-31 nuclear magnetic resonance studies. Plant Physiol. 2001;125(2):912-25. https://doi.org/10.1104/pp.125.2.912

52. Ferreira de Sousa, FA, Sodek L. The metabolic response of plants to oxygen deficiency. Braz J Plant Physiol. 2002; 14(2):83-94. 04202002000200002

53. Rocha M, Licausi F, Araujo WL, Nunes-Nesi A, Sodek L, Fernie $\mathrm{AR}$, et al. Glycolysis and the tricarboxylic acid cycle are linked by alanine aminotransferase during hypoxia induced by waterlogging of Lotus japonicus. Plant Physiol. 2010; 152(3):1501-13. https://doi.org/10.1104/pp.109.150045

54. Maricle BR, White SJ, Meraz A, Maforo NG, Biggs TN, Martin $\mathrm{NM}$, et al. Effect of ethanol toxicity on enzyme activity in anaerobic respiration in plants. Trans Kans Acad Sci. 2014; 117(3-4):237-44. https://doi.org/10.1660/062.117.0309

55. Arcara PG, Ronchi VN. Effect of ethyl alcohol on the mitotic cycle of Allium cepa root meristems. Caryologia. 1967; 20(3):229-32. https://doi.org/10.1080/00087114.1967.10796261

56. Perata P, Alpi A, Loschiavo F. Influence of ethanol on plant cells and tissues. J. Plant Physiol. 1986; 126(2-3):181-88. https:/ doi.org/10.1016/S0176-1617(86)80019-0

57. Dordas C, Rivoal J, Hill RD. Plant haemoglobins, nitric oxide and hypoxic stress. Ann Bot. 2003;91(2):173-178. https://doi.org/ 10.1093/aob/mcf115

58. Voesenek LACJ, Sasidharan R, Visser EJW, Bailey-Serres J. Flooding stress signaling through perturbations in oxygen, ethylene, nitric oxide and light. New Phytol. 2016;209(1):39-43. https://doi.org/10.1111/nph.13775

59. Bai X, Long J, He X, Yan J, Chen X, Tan Y, Li K, Chen L, Xu H. Overexpression of spinach non-symbiotic hemoglobin in Arabidopsis resulted in decreased NO content and lowered nitrate and other abiotic stresses tolerance. Sci Rep. 2016 6:26400. https://doi.org/10.1038/srep26400

60. Du H, Shen X, Huang Y, Huang M, Zhang Z. Overexpression of Vitreoscilla hemoglobin increases waterlogging tolerance in Arabidopsis and maize. BMC Plant Biol. 2016;16(1):35. https://doi.org/10.1186/s12870-016-0728-1

61. Li X, Peng R, Fan H, Xiong A, Yao Q, Cheng Z, Li Y. Vitreoscilla hemoglobin overexpression increases submergence tolerance in cabbage. Plant Cell Rep. 2005;23(10-11):710-15. https://doi.org/10.1007/s00299-004-0872-1

62. Sairam RK, Kumutha D, Ezhilmathi K. Waterlogging tolerance: nonsymbiotic hemoglobin-nitric oxide homeostasis and antioxidants. Curr Sci. 2009;96(5):674-82

63. Poole RK. Oxygen reactions with bacterial oxidases and globins: binding, reduction and regulation. Anton. Leeuw. 1994;65(4):289-310. https://doi.org/10.1007/BF00872215

64. Fan TWM, Lane AN, Higashi RM. In vivo and in vitro metabolomic analysis of anaerobic rice coleoptiles revealed unexpected pathways. Russ J Plant Physiol. 2003; 50(6):787-93. https://doi.org/10.1023/B:RUPP.0000003276.14947.16

65. Perazzolli M, Romero-Puertas MC, Delledonne M. Modulation of nitric oxide bioactivity by plant hemoglobins. J Exp Bot. 2006; 57(3):479-488. https://doi.org/10.1093/jxb/erj051

66. Igamberdiev AU, Baron K, Manac'h-little N, Stoimenova M, Hill $\mathrm{R}$. The hemoglobin/nitric oxide cycle: involvement in flooding stress and effects on hormone signalling. Ann Bot. 2005 96(4):557-64. https://doi.org/10.1093/aob/mci210

67. Bethke PC, Badger MR, Jones RL. Apoplastic synthesis of nitric oxide by plant tissues. Plant Cell. 2004;16(2):332-41. https://doi.org/10.1105/tpc.017822

68. Wink DA, Mitchell JB. Chemical biology of nitric oxide: insights into regulatory, cytotoxic, and mechanisms of nitric oxide. Free Radic Biol Med. 1998;25(4-5):434-56. https://doi.org/10.1016/S0891-5849(98)00092-6

69. Rubio-Cabetas MJ, Pons C, Bielsa B, Amador ML, Marti C, Granell A. Preformed and induced mechanisms underlies the differential responses of Prunus rootstock to hypoxia. J Plant Physiol. https://doi.org/10.1016/j.jplph.2018.06.004

2018;228:134-49.

70. hu X, Li X, Jiu S, Zhang K, Wang C, Fang J. Analysis of the regulation networks in grapevine reveals response to waterlogging stress and candidate gene-marker selection for 
damage severity. Royal Soc Open Sci. 2018;5:172253. http://dx.doi.org/10.1098/rsos.172253

71. Parthasarathy A, Adams LE, Savka FC, Hudson AO. The Arabidopsis thaliana gene annotated by the locus tag At3g08860 encodes alanine aminotransferase. Plant Direct. 2019; 3(9):e00171. https://doi.org/10.1002/pld3.171

72. Diab H, Limami AM. Reconfiguration of $\mathrm{N}$ metabolism upon hypoxia Stress and recovery: roles of alanine aminotransferase (AlaAT) and glutamate dehydrogenase (GDH). Plants. https://doi.org/10.3390/plants5020025

73. Zeggiani R, Cantu CA, Brambilla I, Bertani A. Accumulation and interconversion of amino acids in rice roots under anoxia. Plant Cell Physiol. 1988;29(6):981-87. https://doi.org/10.1093/oxfordjournals.pcp.a077604

74. Wagner S, Steinbeck J, Fuchs P, Lichtenauer S, Elsasser M, Schippers JHM, Nietzel T, Ruberti C, Aken OV, Dongen JTV, Schmidt RR, Schwarzlander M. Multiparametric real-time sensing of cytosolic physiology linkshypoxia responses to mitochondrial electron transport. New Phytol. 2019; 224(4):1668-84. https://doi.org/10.1111/nph.16093

75. Sweetlove LJ, Beard KFM, Nunes-Nesi A, Fernie AR, Ratcliffe RG. Not just a circle: flux modes in the plant TCA cycle. Trends Plant Sci. https://doi.org/10.1016/j.tplants.2010.05.006

76. Lu Y, Wu Y, Han B. Anaerobic Induction of Isocitrate Lyase and Malate Synthase in Submerged Rice Seedlings Indicates the Important Metabolic Role of the Glyoxylate Cycle. Acta Biochim Biophys Sin. 2005;37(6):406-14. https://doi.org/10.1111/ j.1745-7270.2005.00060.x

77. Miro B, Ismail AM. Tolerance of anaerobic conditions caused by flooding during germination and early growth in rice (Oryza sativa L.). Front Plant Sci. 2013;4:269. https://doi.org/10.3389/fpls.2013.00269

78. Lakshmanan M, Zhang Z, Mohanty B, Kwon J, Choi H, Nam H, Kim D, Lee D. Elucidating rice cell metabolism under flooding and drought stresses using flux-based modeling and analysis. Plant Physiol. https://doi.org/10.1104/pp.113.220178 2013;162(4):2140-50.

79. Yemelyanov VV, Shishova MF, Chirkova TV, Lindberg SM. Anoxia-induced elevation of cytosolic $\mathrm{Ca} 2+$ concentration depends on different $\mathrm{Ca} 2+$ sources in rice and wheat protoplasts. Planta. 2011;234(2):271-80. https://doi.org/10.1007/ s00425-011-1396-X

80. Wang F, Chen Z, Liu X, Colmer TD, Zhou M, Shabala S. Tissuespecific root ion profiling reveals essential roles of the CAX and ACA calcium transport systems in response to hypoxia in Arabidopsis. J Exp Bot. 2016;67(12):3747-62. https://doi.org/10.1093/jxb/erw034

81. Schmidt RR, Weits DA, Feulner CFJ, van Dongen JT. 2018. Oxygen sensing and integrative stress signaling in plants. Plant Physiol. 2018;176:1131-42. https://doi.org/10.1104/pp.17.01394

82. He L, Li B, Lu X, Yuan L, Yang Y, Yuan Y, Du J, Guo S. The effect of exogenous calcium on mitochondria, respiratory metabolism enzymes and ion transport in cucumber roots under hypoxia. Sci Rep. 2015;5:11391. https://doi.org/10.1038/srep11391

83. Miyashita Y, Good AG. Contribution of the GABA shunt to hypoxia-induced alanine accumulation in roots of Arabidopsis thaliana. Plant Cell Physiol. 2008;49(1):92-102. https://doi.org/10.1093/pcp/pcm171

84. Subbaiah CC, Zhang J, Sachs MM. Involvement of Intracellular Calcium in Anaerobic Gene Expression and Survival of Maize $\begin{array}{lll}\text { Seedlings. } & \text { Plant } & \text { Physiol. }\end{array}$ https://doi.org/10.1104/pp.105.1.369

85. Gao H, Jiaa Y, Guoa S, Lv G, Wanga T, Juan L. Exogenous calcium affects nitrogen metabolism in root-zone hypoxiastressed muskmelon roots and enhances short-term hypoxia tolerance. J Plant Physiol. 2011;168(11):1217-25. https://doi.org/ 10.1016/j.jplph.2011.01.022

86. Shi K, Ding X, Dong D, Zhou Y, Yu JQ. Putrescine enhancement of tolerance to root-zone hypoxia in Cucumis sativus: a role for increased nitrate reduction. Funct Plant Biol. 2008;35(4):33745. https://doi.org/10.1071/FP08029

87. Aarnes H, Eriksen AB, Petersen D, Rise F. Accumulation of ammonium in Norway spruce (Picea abies) seedlings measured by in vivo 14N-NMR. J Exp Bot. 2007;58(5):929-34. https://doi.org/10.1093/jxb/erl247

88. Drew MC, He C, Morgan PW. Programmed cell death and aerenchyma formation in roots. Trends Plant Sci. 2000; 5(3):123-27. https://doi.org/10.1016/S1360-1385(00)01570-3

89. Song L, Valliyodan B, Prince S, Wan J, Nguyen HT. Characterization of the XTH Gene Family: New Insight to the Roles in Soybean Flooding Tolerance. Int J Mol Sci. 2018; 19(9):2705. https://doi.org/10.3390/ijms19092705

90. Lemichez E,WuY, Sanchez J, Mettouchi A, Mathur J, Chua N. Inactivation of AtRac1 by abscisic acid is essential for stomatal

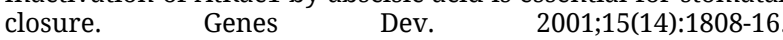
https://doi.org/10.1101/gad.900401

91. Sagi M, Fluhr R. Superoxide production by plant homologues of the gp91phox NADPH oxidase. modulation of activity by calcium and by tobacco mosaic virus infection. Plant Physiol. 2001;126(3):1281-90. https://doi.org/10.1104/pp.126.3.1281

92. Bailey-Serres J, Baxter-Burrell A, Yang Z, Springer PS. RopGAP4-dependent Rop GTPase Rheostat control of Arabidopsis oxygen deprivation tolerance. Science. 2002; 296(5575):2026-28. https://doi.org/10.1126/science.1071505

93. Steffens B, Sauter M. G proteins as regulators in ethylenemediated hypoxia signaling. Plant Signaling \& Behavior 2010; 5(4):375-78

94. Etherington AM, Hunter MIS, Crawford RMM. Contrasting effects of anoxia on rhizome lipids in Iris species. Phytochem. 1982;21:1275-78. https://doi.org/10.1016/0031-9422(82)80125-8

95. Roberts JKM, Callis J, Jardetzky O, Walbot V, Freeling M. Cytoplasmic acidosis as a determinant of flooding intolerance in plants. 1984;81(19):6029-33. https://doi.org/10.1073/pnas.81.19.6029

96. Hanhijarvi AM, Fagerstedt KV. Comparison of the effect of natural and experimental anoxia on carbohydrate and energy metabolism in Iris pseudacorus rhizomes. Physiol Plant. 1994 90(3):437-44. https://doi.org/10.1111/j.1399-3054.1994.tb08799.x

97. Miller, G, Schlauch K, Tam R, Cortes D, Torres MA, Shulaev V, et al. The plant NADPH Oxidase RBOHD mediates rapid systemic signaling in response to diverse stimuli. Sci Signal. 2009; 2(84):a45. https://doi.org/10.1126/scisignal.2000448

98. Suzuki N, Koussevitzky S, Mittler R, Miller G. ROS and redox signalling in the response of plants to abiotic stress. Plant Cell Environ. 2012;35(2):259-70. $\quad$ https://doi.org/10.1111/j.13653040.2011.02336.x

99. Blokhina OB, Chirkova TV and KV. Fagerstedt. Anoxic stress leads to hydrogen peroxide formation in plant cells. J Exp Bot. 2001;52:1179-90. https://doi.org/10.1093/jexbot/52.359.1179

100. Moller IM. Plant mitochondria and oxidative stress: electron transport, NADPH turnover and metabolism of reactive oxygen species. Annu Rev Plant Physiol Plant Mol Biol. 2001; 52: 56191. https://doi.org/10.1146/annurev.arplant.52.1.561

101. Vergara R, Parada F, Rubio S, Perez FJ. Hypoxia induces H2O2 production and activates antioxidant defence system in grapevine buds through mediation of $\mathrm{H} 2 \mathrm{O} 2$ and ethylene. Exp Bot. 2012;63(11):4123-31. https://doi.org/10.1093/jxb/ers094

102. Zhang Y, Ou L, Zhao J, Liu Z, Li X. Transcriptome analysis of hot pepper plants identifies waterlogging resistance related genes. Chil J Agr Res. 2019;79(2):296-306. https://doi.org/10.4067/S0718-58392019000200296

103. Blokhina O, Fagerstedt KV. Oxidative metabolism, ROS and NO under oxygen deprivation. Plant Physiol Bioch. 2010;48(5):35973. https://doi.org/10.1016/j.plaphy.2010.01.007

104. Noctor G, Foyer $\mathrm{CH}$. Ascorbate and Glutathione: keeping active oxygen under control. Annu Rev Plant Physiol Plant Mol Biol. 1998;49:249-79. https://doi.org/10.1146/annurev.arplant.49.1.249 